\title{
Preparation of One-page Lesson Plan for German Teachers in Malang
}

\author{
Edy Hidayat $^{(1)}$, M. Kharis ${ }^{(2)}$, Dewi Kartika Ardiyani( ${ }^{(3)}$, Herri Ahmad Bukhori( ${ }^{(4)}$ \\ Universitas Negeri Malang, Indonesia \\ Email: ${ }^{(1)}$ edy.hidayat.fs@um.ac.id, ${ }^{(2)}$ m.kharis.fs@um.ac.id, ${ }^{(3)}$ dewi.kartika.fs@um.ac.id, \\ ${ }^{(4)}$ herri.akhmad.fs@um.ac.id
}

Received: 12 November 2021; Revised: 28 November 2021; Accepted: 29 November 2021

\begin{abstract}
The one-page lesson plan (LP) is one of four new policies announced by the Indonesian Ministry of Education and Culture several years ago. LP is prepared so that teachers have plenty of time to prepare and evaluate the learning process. The training on how to design a one-page LP provides new experiences for teachers, who are members of the German Teachers Association (IGBJI) in Malang. Based on the results of the questionnaire, more than half of the participants stated that the design of the one-page LP was easier than the old one because the new design had components that were more concise and streamlined, made it efficient in many ways. Although the teachers still have shortcomings, but in general, it can be stated that the use of a one-page LP can help teachers to have an orientation in teaching.
\end{abstract}

Keywords: one-page, lesson plan, german teachers

\section{Introduction}

The curriculum's implementation instructs that the LP should be developed in detail referred to the syllabus. A LP at least contains subject identity, indicators of competency achievement, learning objectives, teaching materials, learning resources, media, learning activities, and assessment (Wicaksono \& Pristiwati, 2020). There is an LP which contains even more details, by conveying information about classes/semesters, time needed, basic competencies; learning methods; media, tools, and steps for learning activities. In short, compiling an ideal LP that fits the grid in the Permendikbud is difficult, because of the complexity of its substance and essence.

The contents of an LP and with its very detailed borne by teachers in preparing LP. The difficulties of teachers in preparing LP are clearly described by Wikanengsih et al. This study reveals, that teachers have difficulty in preparing LP. This is due to several factors, including their lack of ability in the field of knowledge of LP preparation theory according to the reference's frame of the Minister of Edu- cation and Culture (Wikanengsih et al., 2015), and the teacher's low ability to compile a complete and systematic syllabus and LP(Gede, 2020).

The one-page LP is one of the four new policies of the Indonesian Ministry of Education and Culture in coordination meetings with Provincial and District/City Education Offices. The preparation of a one-page LP is primary so that teachers are better at preparing and evaluating the learning process. With this one-page LP, the teacher is expected to be able to reflect on learning, so that it can improve their performance in the future. Based on the above background, the focus of this community service activity can be formulated as follows: 1) how do German language teachers who are members of the IGBJI (Indonesian German Language Teachers Association) in Malang design and compile a one-page LP? 2) What is the difference between the old LP and the 1- page LP?

\section{Materials and Method}

The method used in the community service activities is as follows: 
Table 1: Workshop Activity Plans

\begin{tabular}{|c|c|}
\hline Workshop & Activities \\
\hline 1 & $\begin{array}{c}\text { Introduction to prototype models and preparation } \\
\text { of one-page LP. }\end{array}$ \\
\hline 2 & Assistance in the preparation of LP \\
\hline 3 & Implementation of learning, FGD, and evaluation \\
\hline
\end{tabular}

Table 2: One-page LP design

\begin{tabular}{|c|c|c|c|c|c|}
\hline \multirow{2}{*}{ No. } & Statement & SA & A & DA & SDA \\
\cline { 3 - 6 } & \multicolumn{3}{|c|}{ in percentage } \\
\hline 1 & $\begin{array}{c}\text { Before attending this training, I was familiar with } \\
\text { the concept of a one-page LP design. }\end{array}$ & 0 & 55 & 45 & 0 \\
\hline 2 & $\begin{array}{c}\text { Before attending this training, I was able to com- } \\
\text { pile a one-page LP }\end{array}$ & 0 & 36 & 64 & 0 \\
\hline 3 & $\begin{array}{c}\text { A one-page LP helps me prepare learning activi- } \\
\text { ties. }\end{array}$ & 9 & 91 & 0 & 0 \\
\hline 4 & In my opinion, compiling a one-page LP is easy. & 0 & 27 & 73 & 0 \\
\hline
\end{tabular}

a. Lectures: seminars on lesson plans according to regulations.

b. The demonstration: demonstrates to prepare a LP.

c. The practice of compiling a one-page LP.

d. Assistance in the preparation and implementation of LP in the class in the form of Lesson Study (LS).

The activity was carried out in the form of several workshops with an overview of the activities as Table 1. Implementation of mentoring and workshops is useful for training skills in preparing a one-page LP. At the end of each workshop, participants filled out a questionnaire. To get good and accurate data, researchers used questionnaires and observations. Each question in the questionnaire has four alternative answers to the Likert scale: Strongly Agree (SA), Agree (A), Disagree (DA), Strongly Disagree (SDA).

\section{Results and Discussion Workshop I}

In the first workshop, a seminar on the concept and design of a 1 page LP was conducted at SMAN 2 Malang. 10 German teachers in
Malang attended the activity. After the seminar the participants filled out a questionnaire as Table 2.

After the seminar, most participants can understand better how the concept of the preparation of a one-page LP. However, most stated that the preparation of a one-page LP was not easy. The seminar activity was continued with training and mentoring activities, to assist and support teachers in compiling a one-page LP. This activity was carried out at the second meeting which will be described below.

\section{Workshop II}

In the second workshop, the teacher attended a workshop on the design of a one-page LP. The 12 participating teachers attended the training to compile a one-page LP manuscript and were accompanied by the lecturer. After the workshop the participants filled out the following questionnaire:

In addition to filling out a closed questionnaire, participants also filled out an open questionnaire to reveal their likes and dislikes about the one-page LP. The impressions and comments about this are shown in the following table:

- $\quad$ help me to compile and clarify the learn- 
Table 3: One-page LP

\begin{tabular}{|c|c|c|c|c|c|}
\hline \multirow[t]{2}{*}{ No. } & \multirow[t]{2}{*}{ Statement } & SA & A & $\overline{\mathrm{DA}}$ & $\begin{array}{l}\mathrm{SD} \\
\mathrm{A}\end{array}$ \\
\hline & & \multicolumn{4}{|c|}{ in percentage } \\
\hline 1 & $\begin{array}{l}\text { The draft of the one-page LP is easier than the old } \\
\text { LP }\end{array}$ & 60 & 40 & 0 & 0 \\
\hline 2 & The one-page LP has a more concise formula & 70 & 30 & 0 & 0 \\
\hline 3 & one-page LP design becomes more systematic. & 50 & 50 & 0 & 0 \\
\hline 4 & The one-page LP doesn't repeat sentences & 30 & 50 & 20 & 0 \\
\hline 5 & Textbooks play a role in learning. & 20 & 70 & 10 & 0 \\
\hline
\end{tabular}

ing steps

- textbooks help me in making material mapping and related to the learning material.

Several factors that make the one-page LP easier are as follows:

- I don't use detailed, long, and wordy sentences

- I don't have to look at the syllabus often

- I just wrote the outline.

- The learning tives become clearer.

objec-

- Learning material can be sequential and systematic

- I saved a lot of time.

- I use language that is easier to understand

Even though it has several advantages, teachers still have difficulties when compiling a one-page LP. Some of the difficulties include:

- I must consider many things, especially in the learning online

- I have to determine the right learning media

- It means simplifying sentences

- Many teachers are not familiar with the format

- I determine the goal at each meeting

- It is difficult to determine a time allocation

- It is difficult to find material sources on the internet that are open sources.

According to the teachers, the one-page LP form was still not ideal. Here are some suggestions in the concept of a one-page LP, including the format's layout and form of assessment.
Workshop III

Lesson Study aims to increase the knowledge about how teachers perform teaching through collaboration in school (Lundbäck \& Egerhag, 2020) along with other teachers. A model teacher did a project pilot. Pilot activities are carried out online because face-to-face learning is still not possible related to the pandemic. The recording of the application of the one-page LP preparation can be listened to via the following link:

https://drive.google.com/folderview? id=1NtHODRivW5OOgibDgyHt5DfXV008RDf $\underline{3}$

After the learning process, the observers filled out a questionnaire. Based on the questionnaire, more than half of the observers stated that the model teacher appeared confidently in front of the class, and in general, it could be stated that the one-page LP helped the model teacher's orientation in teaching. However, the preparation of the one-page LP has the potential to disrupt the educational process. For example, the teacher requires a long explanation at a certain learning step. Besides, the different LP formats in each school also make it difficult for teachers to compile a one-page LP. Teachers need material attachments that accompany the one-page LP.

LP stands for Learning Implementation Plan (LIP) which contains a written description of planned learning activities that should be implemented in learning practices (Amin et al., 2020). Thus the LP can be used as a teacher's orientation in delivering learning material in class. Planning the steps for good and directed learning activities can be used to achieve learning objectives (Rozaq, 2019). LP preparation must be based on established guidelines. The stages in the preparation of LP are carried out by preparing learning tools, compiling and selecting methods, strategies, media, and class assessments, and finding 
materials that suit the needs (Ni'maturrohmah, 2020).

Research on the difficulties of teachers in preparing LP is widely carried out. School Action Research (PTS) by Saragi shows that coaching and mentoring 10 teachers in the LP preparation process has a positive impact on teachers (Saragih, 2016). Research by Chusni et al. showed an increase in the ability of physics teachers in Bandung in preparing LP (Chusni et al., 2017).

The lesson plan is prepared to design one or more face-to-face lessons. LP preparation must apply the principle of pedagogical steps in writing completely and systematically. Thus students can gain learning experience in developing attitudes, knowledge, and skills following predetermined learning objectives.

Through the systematic development of LP, learning is carried out to be efficient and can help students participate actively. LP includes 13 components (Syaharuddin \& Mutiani, 2020) which are then simplified to help reduce the burden on teachers in learning administration matters (Octavia, 2020; Wahidmurni, 2020). The new LP design at least has components of learning objectives, learning steps, and learning assessments. Other components are only as supplements.

The methods for preparing LP are included academic supervision, workshops, and mentoring. Suyatmini in his research stated that the method of academic supervision with classroom observation techniques can improve the competence of preparing LP and implementing learning for teachers (Suyatmini, 2020). Mizar's research also shows that the implementation of academic supervision for teachers in developing LP has a positive impact (Mizwar, 2020). Also, Mandirisari's research results show that the clinical supervision model can improve the ability of teachers to make LP (Mandirisari, 2020).

Meanwhile, Khairani's research results show that workshop activities can improve teachers' abilities in preparing LP (Khairani, 2020). In addition to supervision and workshops, mentoring is needed both in groups and individually because the implementation of mentoring can improve teacher competence in preparing LP (Wirentanus, 2020). In practice, teachers do not experience difficulties in their preparation and can carry it out according to directions (Octavia, 2020).

\section{Conclusion}

German Teachers In Malang practiced constructing the one-page LP, to have more time to prepare and evaluate the learning process. The training on how they can design a one-page LP has been giving a new experience for teachers, members of the German Teachers Association (IGBJI) Malang. Most of the participants stated that the one-page LP design was easier than the old one because the new had a more concise learning component which made it efficient in many ways. but in general, it can be stated that the use of a one-page LP can help teachers to have an orientation in teaching.

\section{References}

Amin, I., Sukestiyarno, Y. L., Waluya, S. B., \& Mariani, S. (2020). Kualitas Rencana Pelaksanaan Pembelajaran (RPP) dan Implementasinya dalam Pembelajaran Matematika SMA. JNPM (Jurnal Nasional Pendidikan Matematika), 4(1), 125-141. https://doi.org/10.33603/jnpm.v4i1.2914

Chusni, M. M., Setya, W., Agustina, R. D., \& Malik, A. (2017). Peningkatan Kemampuan Menyusun Rencana Pelaksanaan Pembelajaran (RPP) Berbasis Saintifik bagi Calon Guru Fisika. Scientiae Educatia, 6
(2) sc.educatia.v6i2.1952

Gede, P. (2020). Upaya peningkatan kemampuan guru dalam menyusun silabus dan rencana pelaksanaan pembelajaran (RPP) melalui diskusi kelompok terfokus di SMAN 1 Waingapu. Indonesian Journal of Educational Development, 1(1), 13-27. https:// doi.org/10.5281/zenodo.3760430

Khairani, K. (2020). Workshop Peningkatan Kemampuan Guru dalam Penyusunan RPP. Jurnal Kinerja Kependidikan (JKK), 2(3), 403-415.

Lundbäck, B., \& Egerhag, H. (2020). Lesson Study as a bridge between two learning contexts. International Journal for Lesson \& Learning Studies, 9(3), 289-299. https:// doi.org/10.1108/IJLLS-02-2020-0006

Mandirisari, I. S. (2020). Pembinaan Akademik untuk Meningkatkan Kemampuan Guru SMA Sumatera 40 Bandung Membuat Perencanaan Pembelajaran. Juripol, 3(1), $50-63$.

Mizwar, E. (2020). Upaya Meningkatkan Kompetensi Guru dalam Mengembangkan RPP Kurikulum 2013 melalui Pelaksanaan Su- 
pervisi Akademik di SMA Negeri 2 Bireuen. $A L-I L M U, 5(1)$, Article 1. http:// jurnal.kopertais5aceh.or.id/index.php/ AIJKIS/article/view/79

Ni'maturrohmah, W. (2020). Assessment Perencanaan Pembelajaran Guru di SMA Nurul Muttaqin Albarokhah Kota Malang. AL MURABBI, 5(2), 34-40. https:// doi.org/10.35891/amb.v5i2.2136

Octavia, R. (2020). Perspektif dan Pengembangan Model Rencana Pelaksanaan Pembelajaran (RPP) Berdasarkan Surat Edaran Mendikbud no. 14 Tahun 2019 di MAN 1 Kota Malang [Undergraduate, Universitas Muhammadiyah Malang]. http:// eprints.umm.ac.id/68568/

Rozaq, M. I. (2019). Kesesuauan Rencana Pelaksanaan Pembelajaran (RPP) Dengan Pelaksanaan Pembelajaran Bahasa Jepang Di Kelas X SMA. Hikari, 3(2), Article 2. https://jurnalmahasiswa.unesa.ac.id/ index.php/kejepangan-unesa/article/ view/31446

Saragih, H. (2016). Meningkatkan Ketrampilan Guru Membuat Perangkat Pembelajaran Berbasis Kurikulum 2013 bagi Guru pada Sekolah. JUPIIS: JURNAL PENDIDIKAN ILMU-ILMU SOSIAL, 8(2), 114. https:// doi.org/10.24114/jupiis.v8i2.5157

Suyatmini, S. (2020). Peningkatan Kompetensi Menyusun RPP dan Melaksanakan Pembelajaran melalui Supervisi Akademik dengan Teknik Observasi Kelas bagi Guru SD Negeri I Baturetno. Elementary School: Jurnal Pendidikan Dan Pembelajaran KeSD-An, 7(1), 86-96. https:// doi.org/10.31316/esjurnal.v7i1.483

Syaharuddin, \& Mutiani. (2020). Strategi Pembelajaran IPS: Konsep dan Aplikasi. Penerbit Program Studi Pendidikan IPS Fakultas Keguruan dan Ilmu Pendidikan Universitas Lambung Mangkurat.

Wahidmurni, W. (2020, April 13). Rencana pelaksanaan pembelajaran: RPP 1 lembar [Teaching Resources]. http://repository.uinmalang.ac.id/5377/

Wicaksono, H. A., \& Pristiwati, R. (2020). Analysis of Learning Implementation Plan (LIP) of Explanation Text In Class XI Senior High School For Curriculum 2013. International Journal of Active Learning, 5(1), 37-45.

Wikanengsih, W., Nofiyanti, N., Ismayani, M., \& Permana, I. (2015). Analisis Rencana Pelaksanaan Pembelajaran (RPP) Mata
Pelajaran Bahasa Indonesia (Studi terhadap RPP yang Disusun Guru Bahasa Indonesia Tingkat SMP di Kota Cimahi). P2M STKIP Siliwangi, 2(1), 106. https://doi.org/10.22460/p2m.v2i1p106119.170

Wirentanus, W. (2020). Meningkatkan Kompetensi Guru Kelas dalam Penyusunan Rencana Pelaksanaan Pembelajaran (RPP) Kurikulum 2013 melalui Pendampingan Berbasis KKG di SDN Dondak Kec. Pujut Tahun pelajaran 2018/2019”. JISIP (Jurnal Ilmu Sosial Dan Pendidikan), 4(1), Article 1. https://doi.org/10.36312/jisip.v4i1.1021 